\title{
ROLE OF SOCIAL MEDIA ON INFORMATION SHARED ABOUT COVID-19 PANDEMIC: A PERCEPTION OF MEDICAL STUDENTS
}

\section{Community Medicine}

Shrivatshan M.S.B Undergraduate Mbbs Student, Chettinad Hospital And Research Institute, Chettinad Academy Of Research And Education, Kelambakkam, Tamil Nadu 603103.

Dr.Remya.K.J*

\section{Dr.Vinoth Gnana Chellaiyan. D}

Assistant Professor, Department of Physiology, Chettinad Hospital and Research Institute, Chettinad Academy of Research and Education, Kelambakkam, Tamil Nadu 603103.*Corresponding Author

Associate Professor, Department of Community Medicine, Chettinad Hospital and Research Institute, Chettinad Academy of Research and Education, Kelambakkam, Tamil Nadu 603103.

\section{ABSTRACT}

IntroductionThe emergence of the COVID-19 outbreak affected the attention of social media and press. But there are too many sources and sites through which any one can obtain information, and many of them are not credible which resulted in misinformation and difficulties to distinguish between rumours and reality

Subjects and Methods: Cross sectional study was conducted online and 519 students of both sexes belonging to the age group of $18-55$ years studying medicine and allied health courses in various universities of India participated.

Data collection procedure: An online questionnaire of 11 questions as Google forms was created in English and circulated for 3 months in different university students via email to collect the data related to their social media usage during the pandemic COVID-19.

Results $382(73.6 \%)$ participants in this study were less than 20 years old. Females participated, $\mathrm{N}=320(61.7 \%)$ more than the males, $\mathrm{N}=199$ $(38.3 \%)$ in this study. Since this study was circulated predominantly in medical students group, 417 out of $519(80.3 \%)$ were medical professionals. About 46 people who are residing outside India also participated in this study. TV/Radio/ Newspaper were the most searched source of information about COVID-19 among the youth of this part of the India accounting for $50.5 \%(\mathrm{~N}=262)$. A significant association was found between Medical professionals and verification of the authenticity of COVID-19 information $(\mathrm{P}=0.04)$ and Gender of the participants with the influence of the information about COVID-19 from different sources $(\mathrm{P}=0.005)$. The association was found significant between age group and "social media influencers and/or celebrities impact on your information sources" $(\mathrm{P}=0.004)$.

Conclusion: Students in India are clear in their perception on receiving information about COVID-19 through social media.

\section{KEYWORDS}

\section{Social media, COVID-19, Medical students}

\section{INTRODUCTION:}

COVID-19 infection started as pneumonia in patients in China in December 2019. World Health Organization (WHO) named the SARS COV-2 virus as 2019 novel coronavirus (2019-nCoV) in February 2020 and due to its widespread across all the 6 continents, COVID-19 has been declared global pandemic (1). As of December $4^{\text {th }} 2020$, the total number of COVID-19 positive cases in India is over 9.61 million with the over 1,40,000 deaths. Using social media to gain medial information may have significant effect on the physical, mental and social well being of the people, especially at times of national crises and global pandemics. In public health contexts, mass communications whether generated by the private or public sector influence population health by shaping discourse about exposure risk and disease, influencing the adoption or non adoption of healthpromoting social policies, linking people to health services, and providing education and motivation that influence behaviour (2). Despite the ubiquity of health-related content on social media, no consensus has emerged on whether this medium, on balance, jeopardizes or promotes health

During the COVID-19 pandemic, social media has been described by some as the source of a toxic "infodemic" and considered by others as an emerging tool for public health (3). While news outlets have always played an important role in informing and shaping public perception of risk, social media has rapidly become a major driver of what the public understands and responds to. But social media can rapidly spread misinformation across large portions of the public $(4,5)$. The emergence of the COVID-19 outbreak affected the attention of social media and press. But there are too many sources and sites through which any one can obtain information, and many of them are not credible which resulted in misinformation and difficulties to distinguish between rumours and reality. Thus, health care workers and the public must refer to trustworthy sources and information regarding COVID-19 such as WHO which provided social media teams and technical risk communication to respond and track rumours and myths $(6,7)$. The media dependency theory says that, when there is a social problem, there is always a desperate need for the information and social media seems to be fulfilling these needs. Normally these kind of information is gathered by the public to alleviate the anxiety and to exchange the news with others (8). Furthermore, there is an increased pressure on government and other agencies to deliver vital and often life saving information quickly to the masses, as the situation during pandemics is dynamic and ever changing. Therefore, we assessed the usage of social media for medical information among a group of students related to medical field across the world to analyse their social media usage and to extrapolate these results for a larger populace. So the study was designed to analyse relationship between students in the medical field and their trust in social media for medical information during times of global pandemic COVID-19

\section{SUBJECTS AND METHODS:}

Study design: Cross sectional study conducted online.

Study population: Students in students studying medicine and allied health courses in various universities of India. Participants of both sexes belonging to the age group of $18-55$ years.

Sample size: Sample size was calculated to 324. A total of 519 participants completed the questionnaire.

Study duration: The duration of the study was 3 months from May 2020 to July 2020

Data collection procedure: An online questionnaire as Google forms was created in English after thorough search for a questionnaire online with the objectives in consideration, for the different social media users. The questionnaire was circulated for 3 months in different university students via email to collect the data related to their social media usage during the pandemic COVID-19. A total of 11 questions were included in the questionnaire. The questionnaire had two sections, first part which consisted of personal information and second part related to the social media.

Ethical Consideration: The study was approved by Institutional ethical committee. The participants were told about the confidentiality of the answers they have entered. The questionnaire completion was taken as the consent for the study. Confidentiality was ensured. None of the participants were prompted or forced to complete the questionnaire. 
STATISTICAL ANALYSIS: the data obtained from questionnaire were entered in Microsoft Excel and analysed using SPSS, Version 21.0 (IBM SPSS 21.0). Descriptive statistics of the participants data was done. Chi square test was done to find out the association between the data and $\mathrm{P}<0.05$ was taken as significant.

\section{RESULTS}

A total of 519 people participated during the course of the study. Among them, $382(73.6 \%)$ participants were less than 20 years old. Females participated, $\mathrm{N}=320(61.7 \%)$ more than the males, $\mathrm{N}=199$ $(38.3 \%)$ in this study. Since this study was circulated predominantly in medical students group, 417 out of $519(80.3 \%)$ were medical professionals. About 46 people who are residing outside India also participated in this study.

Table 1: Demographic profile of participants

\begin{tabular}{|l|l|l|}
\hline Parameters & Number & \% \\
\hline Age & & \\
\hline less than 20 years & 382 & 73.6 \\
\hline $20-30$ & 110 & 21.2 \\
\hline $31-40$ & 15 & 2.9 \\
\hline $41-50$ & 9 & 1.7 \\
\hline 51 or above & 3 & 0.6 \\
\hline Gender & & \\
\hline Females & 320 & 61.7 \\
\hline Males & 199 & 38.3 \\
\hline Profession & & \\
\hline Medical professional & 417 & 80.3 \\
\hline Non Medical Professional & 102 & 19.7 \\
\hline Residence & & \\
\hline Residing Inside India & 473 & 91.1 \\
\hline Residing Outside India & 46 & 8.9 \\
\hline
\end{tabular}

Even though social media provides the widest used platform for different information, TV/Radio/ Newspaper were the most searched source of information about COVID-19 among the youth of this part of the India accounting for $50.5 \%(\mathrm{~N}=262)$. Next to that were the government and WHO websites searched for information (24.3\%). About $13.1 \%(\mathrm{~N}=68)$ participants only sought the popular social media like Facebook and Instagram.

Table 2: Distribution according to source of COVID 19 information

\begin{tabular}{|l|l|l|}
\hline SI No & Primary Source of information & Number (\%) \\
\hline 1 & Blogs / forums & $14(2.7 \%)$ \\
\hline 2 & Facebook / Instagram / social media & $68(! 3.1 \%)$ \\
\hline 3 & Peers / colleagues & $8(1.5 \%)$ \\
\hline 4 & Scientific literature / Peer - reviewed articles & $11(2.1 \%)$ \\
\hline 5 & TV / Radio / Newspaper & $262(50.5 \%)$ \\
\hline 6 & Whatsapp & $30(5.8 \%)$ \\
\hline 7 & WHO / Government & $126(24.3 \%)$ \\
\hline
\end{tabular}

For finding out the association between the demographic profile of the participants and the source of COVID -19 information, chi-square test was done (Table $3,4,5$ ).

Table 3: Association between verification of authenticity of COVID-19 information with selected variables $(N=519)$

\begin{tabular}{|c|c|c|c|c|}
\hline \begin{tabular}{|l} 
SI \\
No
\end{tabular} & Variable & \begin{tabular}{|l} 
Verify the \\
authenticity
\end{tabular} & \begin{tabular}{|l} 
Did not verify \\
the authenticity
\end{tabular} & $\begin{array}{l}\mathbf{p} \\
\text { value }\end{array}$ \\
\hline \multirow[t]{3}{*}{1} & Sex & & & \multirow[t]{3}{*}{0.116} \\
\hline & Male & $118(41.7 \%)$ & $24(40.7 \%)$ & \\
\hline & Female & $165(58.3 \%)$ & $35(59.3 \%)$ & \\
\hline \multirow[t]{6}{*}{2} & Age group & & & \multirow[t]{6}{*}{0.144} \\
\hline & less than 20 years & $199(70.3 \%)$ & $52(88.1 \%)$ & \\
\hline & $20-30$ & $67(23.7 \%)$ & $6(10.2 \%)$ & \\
\hline & $31-40$ & $10(3.5 \%)$ & $1(1.7 \%)$ & \\
\hline & \begin{tabular}{|l|}
$41-50$ \\
\end{tabular} & $4(1.4 \%)$ & 0 & \\
\hline & 51 or above & $3(1.1 \%)$ & 0 & \\
\hline \multirow[t]{2}{*}{3} & $\begin{array}{l}\text { Medical } \\
\text { Student/Professional }\end{array}$ & $216(76.3 \%)$ & $51(86.4 \%)$ & \multirow[t]{2}{*}{$0.04 *$} \\
\hline & $\begin{array}{l}\text { Non Medical } \\
\text { Student/Professional }\end{array}$ & $67(23.7 \%)$ & $8(13.6 \%)$ & \\
\hline
\end{tabular}

Chi square test applied, $\mathrm{p}$ value $<0.05$ is significant

A significant association was found between Medical professionals and verification of the authenticity of COVID-19 information ( $\mathrm{P}=$ 0.04) [Table.3] and Gender of the participants with the influence of the information about COVID-19 from different sources $(\mathrm{P}=0.005)$ [Table.4].

Table 4: Association between influence of the information about COVID-19 from different sources and selected variables

\begin{tabular}{|c|c|c|c|c|}
\hline $\begin{array}{l}\text { SI } \\
\text { No }\end{array}$ & Variable & $\begin{array}{l}\text { Got influenced } \\
\text { by information } \\
\text { about COVID- } \\
19\end{array}$ & \begin{tabular}{|l|} 
Did not get \\
influenced by \\
information about \\
COVID-19
\end{tabular} & $\begin{array}{l}p \\
\text { value }\end{array}$ \\
\hline \multirow[t]{3}{*}{1} & Sex & & & \multirow[t]{3}{*}{$0.005^{*}$} \\
\hline & Male & $146(43.5 \%)$ & $10(27.8 \%)$ & \\
\hline & Female & $190(56.5 \%)$ & $26(72.2 \%)$ & \\
\hline \multirow[t]{6}{*}{2} & Age group & & & \multirow[t]{6}{*}{0.86} \\
\hline & less than 20 years & $244(72.6 \%)$ & $112(76.2 \%)$ & \\
\hline & $20-30$ & $73(21.7 \%)$ & $28(19.0 \%)$ & \\
\hline & $31-40$ & $10(3.0 \%)$ & $5(3.4 \%)$ & \\
\hline & \begin{tabular}{|l|}
$41-50$ \\
\end{tabular} & $6(1.8 \%)$ & $2(1.4 \%)$ & \\
\hline & 51 or above & $3(0.9 \%)$ & 0 & \\
\hline \multirow[t]{2}{*}{3} & $\begin{array}{l}\text { Medical } \\
\text { Student/Profession } \\
\text { al }\end{array}$ & $216(76.3 \%)$ & $51(86.4 \%)$ & \multirow[t]{2}{*}{0.4} \\
\hline & $\begin{array}{l}\text { Non Medical } \\
\text { Student/Profession } \\
\text { al }\end{array}$ & $67(23.7 \%)$ & $8(13.6 \%)$ & \\
\hline
\end{tabular}

Chi square test applied, $\mathrm{p}$ value $<0.05$ is significant

The association was found significant between age group and "social media influencers and/or celebrities impact on your information sources" $(\mathrm{P}=0.004)[$ Table.5]

Table 5: Association between "Social media influencers and/or celebrities have an impact on your information sources" and selected variables

\begin{tabular}{|c|c|c|c|c|}
\hline \begin{tabular}{|l|} 
SI \\
No
\end{tabular} & Variable & \begin{tabular}{|l|} 
Social media \\
influencers' \\
and/or \\
celebrities have \\
an impact on \\
your information \\
sources - Yes \\
\end{tabular} & \begin{tabular}{|l|} 
Social media \\
influencers' \\
and/or celebrities \\
have an impact \\
on your \\
information \\
sources - No \\
\end{tabular} & $\begin{array}{l}p \\
\text { value }\end{array}$ \\
\hline \multirow[t]{3}{*}{1} & Sex & & & \multirow[t]{3}{*}{0.082} \\
\hline & Male & $35(47.9 \%)$ & $100(39.4 \%)$ & \\
\hline & Female & $38(52.1 \%)$ & $154(60.6 \%)$ & \\
\hline \multirow[t]{6}{*}{2} & Age group & & & \multirow[t]{6}{*}{$0.004 *$} \\
\hline & less than 20 years & $58(79.5 \%)$ & $172(67.7 \%)$ & \\
\hline & $20-30$ & $11(15.1 \%)$ & $68(26.8 \%)$ & \\
\hline & $31-40$ & 0 & $12(4.7 \%)$ & \\
\hline & \begin{tabular}{|l|}
$41-50$ \\
\end{tabular} & $3(4.1 \%)$ & $2(0.8 \%)$ & \\
\hline & 51 or above & $1(1.4 \%)$ & 0 & \\
\hline \multirow[t]{2}{*}{3} & $\begin{array}{l}\text { Medical } \\
\text { Student/Professio } \\
\text { nal } \\
\end{array}$ & $58(79.5 \%)$ & $197(77.6 \%)$ & \multirow[t]{2}{*}{0.196} \\
\hline & $\begin{array}{l}\text { Non Medical } \\
\text { Student/Professio } \\
\text { nal }\end{array}$ & $15(20.5 \%)$ & $57(22.4 \%)$ & \\
\hline
\end{tabular}

Chi square test applied, p value $<0.05$ is significant

\section{DISCUSSION}

The present study was designed in mind with the fact of "infodemics" i.e., various misinformation and false rumours and content about the COVID-19 that was prevalent among the elderly and youngsters alike from the social media in the early stages of this pandemic. A questionnaire study from Jordan by Al-Dmour $\mathrm{H}$ et al concludes that social media platforms positively influence the public (9). Another study done on Egyptian pharmacy students found the dependence of the students on social media over other sources of information. But the information they received from social media platforms were found to be accurate (10). Even though the social media platforms have been blamed for quite a lot of mishap and infodemics, the study by Kristen Malecki and Julie A Keating says that social media offers an opportunity for experts to quickly convey true information about hazards (11). In the present study, $80.3 \%$ of the participants were belonging to medical and allied health sciences and that could be the 
reason that majority of them significantly relied on the government and WHO websites for seeking the information about COVID-19 pandemic.

Number of females $(61.7 \%)$ who participated in this study were more than the males and this relates similar to another study from Jordan which found female gender having significantly increased perception of COVID-19 risk (7). There was a significant association between the gender and the "influence by the source of information" variable in our study. Females were found to be more influenced $(56.5 \%)$ by the COVID-19 information in our study. This finding is comparable to a study from Iraqi Kurdistan which found percentage of females who felt psychological fear about COVID-19 were more than males (12). Many of the students and others in medical field were influenced by the COVID-19 information but it was not significant.

One of the studies, which researched about the tweets about COVID19 by celebrities, politicians found that politicians are really influential and second are celebrities than the health agencies tweets (13). Most of the participants in this study belonged to less than 20 years $(70.3 \%)$ and they were all medical and allied health sciences students $(80.3 \%)$. Normally this is the age group which will be depending too much on the social media and influenced by celebrities at all times. But in this study we found that they were clear about the choices they make in selecting the source of information even in stressful times like this pandemic. This study proves that students in India are clear in their perception on receiving information about COVID-19 through social media.

\section{CONCLUSION}

In this fast pacing world of pandemic, infodemics and social media and celebrities, students in the medical field still trust the government agencies for information related to pandemic like COVID-19.

\section{REFERENCES:}

1. WHO. Current WHO phase of pandemic alert for Pandemic (H1N1) 2009. Accessed on: March 20,2020. Available from: https://www.who.int/csr/disease/swineflu/phase/en/

2. Schillinger D, Chittamuru D, Ramírez AS. From "Infodemics" to Health Promotion: A Schillinger D, Chittamuru D, Ramírez AS. From "Infodemics" to Health Promotion: A
Novel Framework for the Role of Social Media in Public Health [published online ahead of print, 2020 Jun 18]. Am J Public Health. 2020;e1-e4. doi:10.2105/ AJPH. 2020. 305746

3. Giustini D, Ali SM, Fraser M, Kamel Boulos MN. Effective uses of social media in public health and medicine: a system- atic review of systematic reviews. Online J Public Health Inform. 2018;10(2):e215

4. Ophir Y. Coverage of Epidemics in American Newspapers Through the Lens of the Crisis and Emergency Risk Communication Framework. Health Secur. 2018;16(3):147157.

5. Malecki K, Keating JA, Safdar N. Crisis Communication and Public Perception of COVID-19 Risk in the Era of Social Media [published online ahead of print, 2020 Jun 16]. Clin Infect Dis. 2020;ciaa758. doi:10.1093/cid/ciaa758

6. World Health Organisation (WHO). Report Coronavirus Disease 2019 (COVID-19) Situation Report -38

7. Karasneh R, Al-Azzam S, Muflih S, Soudah O, Hawamdeh S, Khader Y. Media's effect on shaping knowledge, awareness risk perceptions and communication practices of pandemic COVID-19 among pharmacists [published online ahead of print, $2020 \mathrm{Apr}$ 23]. Res Social Adm Pharm. 2020;S1551-7411(20)30430-7. doi:10.1016/ j.sapharm. 2020.04.027

8. Liu C, Liu Y Media Exposure and Anxiety during COVID-19: The Mediation Effect of Media Vicarious Traumatization. Int J Environ Res Public Health. 2020;17(13):4720. Published 2020 Jun 30. doi:10.3390/ijerph17134720

9. Al-Dmour H, Masa'deh R, Salman A, Abuhashesh M, Al-Dmour R. Influence of Social Media Platforms on Public Health Protection Against the COVID-19 Pandemic via the Mediating Effects of Public Health Awareness and Behavioral Changes: Integrated Model. J Med Internet Res. 2020 Aug 19;22(8):e19996. doi: 10.2196/19996. PMID: 32750004; PMCID: PMC7439806.

10. Hamza MS, Badary OA, Elmazar MM. Cross-Sectional Study on Awareness and Knowledge of COVID-19 Among Senior pharmacy Students. J Community Health. 2020 Jun 15:1-8. doi: 10.1007/s10900-020-00859-z. Epub ahead of print. PMID: 2020 Jun 15:1-8. doi: $10.1007 / \mathrm{s}$
32542552; PMCID: PMC7295146.

11. Malecki K, Keating JA, Safdar N. Crisis Communication and Public Perception of COVID-19 Risk in the Era of Social Media. Clin Infect Dis. 2020 Jun 16:ciaa758. doi: 10.1093/cid/ciaa 758. Epub ahead of print. PMID: 32544242; PMCID: PMC7337650.

12. Ahmad AR, Murad HR. The Impact of Social Media on Panic During the COVID-19 Pandemic in Iraqi Kurdistan: Online Questionnaire Study. J Med Internet Res. 2020 May 19;22(5):e19556. doi: 10.2196/19556. PMID: 32369026; PMCID: PMC7238863.

13. Kamiński M, Szymańska C, Nowak JK. Whose Tweets on COVID-19 Gain the Most Attention: Celebrities, Political, or Scientific Authorities? Cyberpsychol Behav Soc Attention: Celebrities, Political, or Scientific Authorities? Cyberpsychol Behav Soc
Netw. 2020 Sep 23. doi: 10.1089/cyber.2020.0336. Epub ahead of print. PMID: 32986469 . 